\title{
Facts, truth, and bad journalists in the movies
}

\author{
I Matthew C. Ehrlich \\ University of Illinois at Urbana-Champaign, USA
}

\section{ABSTRACT}

Scholars have called for cultural analyses of the press that are more attuned to journalists' self-image as disciples of facts and truth while also critically examining the contradictions within that self-image. Popular representations of journalism such as motion pictures are one fruitful site of inquiry. This article studies American movies' depictions of 'bad journalists', characters who in many ways contradict the image of upstanding professionalism that the press tries to promote. Although real-life journalists over the years have often objected to such portrayals, 'bad journalist' characters still have helped shore up the press's preferred self-image, either by seeing through lies and pretense to the truth or by paying the price for not telling the truth.

KEY WORDS I cultural analyses of journalism - film genre ! myth ! popular culture I representations of journalism

Scholars have long extolled the virtues of nuanced cultural analyses of journalism. Carey (1988: 15) has written that to view the press through the lens of myth and ritual is to see in a miraculously discontinuous world persistent practices by which that world is sedimented and held together'. It also provides insight into how journalists 'maintain and repair. . their cultural image as journalists in the eyes of a wider world' (Schudson, 1991: 155). Zelizer (2004: 187, 190) argues that cultural studies should be more attuned to how that image is distinguished by 'journalism's reverence for facts, truth, and reality'. At the same time, she says scholars must critically examine the contradictions within journalism's self-image, including those between its 'informative, civic, and rational sides' and its 'pleasure-inducing, entertaining, or simply affective ones'.

Popular representations of journalism such as novels, plays, and movies have been fruitful sites for such inquiry. Many have been written by onetime journalists and hence afford an opportunity to view 'journalism through 
journalism's own eyes' while also questioning 'the self-presentations that journalists provide' (Zelizer, 2004: 176, 198-9). Such popular representations have helped perpetuate 'the heroic image of the journalist defending the truth against the many dragons of darkness in the modern world' (Dahlgren, 1992: 1). That is, they have reconciled journalism's civically minded and pleasureinducing sides by telling romantic, entertaining tales of journalists who uphold their idealized roles as public servants. In so doing, popular culture has provided models for real-life journalistic conduct, with the film of All the President's Men (1976) a prime example. Schudson (1992: 126) says it has promoted journalism's 'central myth', that two young reporters and their newspaper brought down a corrupt president. Brennen (2003: 115) similarly describes All the President's Men as 'a seminal text that illustrates a specific structure of feeling regarding appropriate press behavior in contemporary society'.

In contrast, this article examines texts that have graphically depicted what most real-life journalists would characterize as inappropriate press behavior. From at least the 1928 stage debut of The Front Page, popular culture has presented portrayals of 'bad journalists' who, in many ways, contradict the image of upstanding, ethical professionalism that the press tries to promote (Black et al., 1999; Kovach and Rosenstiel, 2001). Such portrayals have regularly appeared in Hollywood movies, and journalists and press organizations over the years have often objected to them. However, 'bad journalist' characters actually have helped shore up the press's preferred self-image, either by seeing through lies and pretense to the truth or by paying the price for not telling the truth.

\section{Genre movies, myth, and journalism}

Movies and other popular texts 'can be read as a culture thinking out loud about itself' (Mukerji and Schudson, 1991: 23). Genre movies are an example. They are typically structured around conflicts between characters who represent competing cultural values. The films' resolutions (the Western hero vanquishes the villain; the protagonists of a romantic comedy or musical overcome their differences and unite) buttress cultural norms (Altman, 1987; Ray, 1985; Schatz, 1981; Wright, 1975). As such, the movies are powerful purveyors of myth, a key role of which is 'to resolve basic oppositions at the heart of human life' in a way that typically 'affirms the status quo, confirms the way things are, and sustains the current social order' (Lule, 2001: 144, 191).

That is not to say the myths are completely static or the movies are completely uncritical. 'If genres develop and survive because they repeatedly 
flesh out and reexamine cultural conflicts', writes Schatz (1981: 35), 'then we must consider the possibilities that genres function as much to challenge and criticize as to reinforce the values that inform them.' Movies call attention to a culture's intractable rifts and contradictions even as they ultimately tend to smooth over those rifts and contradictions.

Ray (1985: 58-62) argues that Hollywood movies of all genres have historically addressed the tensions between a 'pair of competing myths: the outlaw hero and the official hero'. 'Official' characters, who frequently are professionals such as teachers or lawyers, represent 'the American belief in collective action, and the objective legal process that supersede[s] private notions of right and wrong'. In contrast, 'outlaw' characters represent 'that part of the American imagination valuing self-determination and freedom from entanglements'. 'Outlaws' refer not only to those who explicitly break the law, as seen in Westerns, gangster films, and 'hardboiled-detective' films (Schatz, 1981: 45-149; Slotkin, 1998). Ray (1985: 59-61) also cites as outlaw types such figures from American literature and myth as Davy Crockett, Huckleberry Finn, and Holden Caulfield, whose shared 'distrust of civilization' and 'distrust of politics' contrasts with 'official' characters' respect for social order and adult obligations (see also Kaufman et al., 2005).

The outlaw and official visions reflect 'American culture's traditional dichotomy of individual and community' (Ray, 1985: 58) and never can be fully reconciled. Still, that has not stopped the movies from trying to do just that. (A prominent example is Casablanca, in which Humphrey Bogart's 'outlaw' hero sticks his neck out for nobody before finally demonstrating the 'official' virtues of taking up a cause greater than himself and working for the common good.) In so doing, Ray (1985: 63) argues that the movies have perpetuated 'an ideology of improvisation, individualism, and ad hoc solutions for problems depicted as crises'. That in turn has helped maintain the status quo by masking social divisions and discouraging a systemic, collective response to society's ills.

Similar themes appear in movies about journalism, which have long constituted their own distinct genre with stock characters and relationships (Barris, 1976; Brennen, 2004; Ghiglione, 1990; Ghiglione and Saltzman, 2002; Good, 1989, 1998, 2000; Langman, 1998; Ness, 1997; Saltzman, 2002). Like other genre movies, they reproduce myths: 'sacred, societal stor[ies]' that offer 'exemplary models for human life' (Lule, 2001: 15). In analyzing the mythic status that Watergate and All the President's Men hold for journalists, Schudson (1992: 124) argues that myth's role is 'not to tell us in empirical detail who we are but what we may have been once, what we might again become, what we would be like "if"'.

In those ways, Hollywood presents visions of what the press could and should be, including that of 'journalists as defenders of society's right to know, 
civic virtue and the underdog' (Vaughn and Evensen, 1991: 829). That in turn helps journalists 'maintain their cultural authority as spokespeople for events in the public domain' (Zelizer, 2004: 176). One historian has labeled All the President's Men 'a milestone in the process of exalting the press' and 'a significant moment in the elevation of the American journalist to mythical status' (Leuchtenburg, 1995: 291).

Such celebrations of the press have appeared throughout the history of the journalism movie genre while responding to changes in social and historical context. During the Second World War, reporters were portrayed as dedicated patriots as the Hollywood studios worked closely with the government to boost the war effort (Vaughn and Evensen, 1991). In the immediate postwar era, pictures such as Gentleman's Agreement (1947), Call Northside 777 (1948), and Deadline, USA (1952) reflected a growing emphasis on conscientious professionalism within journalism in depicting the press uncovering antiSemitism and municipal corruption. Recent years have seen movies such as The Insider (1999), in which a television news producer fights to air an exposé of the tobacco industry in the face of pressures brought on by corporate conglomeration.

However, journalists themselves assert that those sorts of heroic portrayals are comparatively rare. Far more common, they say, are depictions implying that 'journalists are hard-drinking, foul-mouthed, dim-witted social misfits concerned only with twisting the truth into scandal and otherwise devoid of conscience' (Rowe, 1992: 27). Nor is this a new assertion. Although some (Fallows, 1997; Hanson, 1996) have argued that contemporary movies treat the press more harshly than the films of Hollywood's golden era, as early as 1931 journalism educator John Drewry (1931: 14) was lambasting Hollywood for making 'the reporter more nearly resemble a gangster than even a moderately well-off business or professional man'.

That points toward a long-standing dichotomy in journalism's self-image roughly corresponding to the competing official and outlaw visions of which Ray (1985) writes. On the one hand, journalists who sought to distinguish the respectable press from the tabloid newspapers and the growing public relations field were by the 1920s promoting journalism as a distinct profession, guided by its own codes of ethics and the overriding principle of objectivity (Evensen, 1989; Schudson, 1978). Journalists today are far more likely to acknowledge that complete objectivity is impossible, but they still stress the press's obligation to verify what it reports and to provide citizens with the truthful information needed for self-governance (Kovach and Rosenstiel, 2001). This professional ideology, with its 'reverence for facts, truth, and reality' (Zelizer, 2004: 187), has much in common with 'official' ideology's commitment toward 'sound reasoning and judgment' on behalf of the public interest (Ray, 1985: 60). 
On the other hand, even as the press sought to boost its occupational standing in the early 20th century, many journalists still were 'reveling in their intimacy with the urban underworld' (Schudson and Tifft, 2005: 24) - that is, identifying themselves as much if not more with the 'gangster' than with the 'moderately well-off business or professional man' (Drewry, 1931: 14) and the middle-class comforts and responsibilities he embodied. Alongside journalism's reverence for heroes such as Woodward and Bernstein has been a persistent fascination with 'bad' journalists who have challenged or ignored professional, 'official' ideals. They can be said to have represented an 'outlaw' sensibility, not so much in being actual lawbreakers (though on occasion that has been the case) as in living by their own rules and thumbing their noses at polite society and authority.

A publication of the Newseum, a professionally sponsored museum devoted to the news industry, gives such characters the label of 'Newsmonger', which it defines as 'the peddler of tales, the one who doesn't let the facts ruin a good story' (Newton, 1999: 2). It cites as one example Janet Cooke, who won a Pulitzer Prize for making up stories altogether (Newton, 1999: 18). It also cites the champion of 'gonzo journalism', Hunter S. Thompson. He embodied 'an American icon, like the gunslinger or the big-city gangster-the bald, paranoid, drug-frenzied journalist, a cigarette holder dangling from the side of his mouth, doing battle with the straight world' (Cohen, 2005: 7). That included the 'straight' press. Thompson declared that '[a]bsolute truth is a very rare and dangerous commodity in the context of professional journalism' and that 'Objective Journalism' was 'a pompous contradiction in terms' (Newton, 1999: 5, 17).

'Newsmongers', however, do not completely reject or contradict journalism's expressed commitment to facts and truth. For all his 'unprofessional' behavior and drunken high jinks, Thompson upon his death was praised for his 'passion for the reporting of the truth [and for] the instructive, persuasive nature of telling a story in the right way' that made him 'a hero to so many' (Keil, 2005: 60, 63). Indeed, his gonzo cynicism helped make him heroic. In the New York Times, Frank Rich (2005: 1) argued that Thompson today would have 'a savage take on our news-free world' dominated by 'counterfeit newsmen', where 'you can't tell the phonies without a scorecard'. The ability to expose phoniness and officially sanctioned falsehoods is central to such characters' appeal. As one observer has written, 'In a society deeply suspicious of the discrepancies between public pronouncement and the hidden workings of power, there is something genuinely attractive about the way a cynic expresses a truth' (Chaloupka, 1999: xv).

As for those such as Janet Cooke, they too have underlined the importance of truth by paying for their transgressions against it. Cooke and more recent journalistic frauds such as the New Republic's Stephen Glass, the New 
York Times' Jayson Blair, and USA Today's Jack Kelley all were publicly pilloried and banished from the profession. Such characters show 'in dramatic fashion what happens to those who challenge or ignore social beliefs' (Lule, 2001: 23), in this case the journalistic belief in truth telling. The purging of those who have violated such beliefs helps journalists engage in 'paradigm repair' and 'boundary maintenance' (Bennett et al., 1985; Berkowitz, 2000; Cecil, 2002; Dahlgren, 1992), reinforcing norms of professional conduct by delineating what is proper and what is not.

Whether they are the subjects of veneration such as Hunter Thompson or vilification such as Janet Cooke, 'newsmonger' journalists help perform the mythic roles of reconciling contradictory values and maintaining the status quo. Carey (2003: 6) argued that the Jayson Blair scandal revealed 'a well-kept secret: The culture of journalism professes loyalty to truth, thoroughness, context and sobriety but actually rewards prominence, the unique take, standing out from the crowd and the riveting narrative'. Those such as Hunter Thompson exemplify the devotion to the unique take and standing out from the crowd. Their 'extreme individualism' provides a bracing counterpoint to the 'blandness', 'repression', and 'boredom' that can be associated with 'official' outlooks (Ray, 1985: 62-3).

At the same time, those such as Cooke, Blair, Glass and Kelley who go too far in breaking the rules allow 'journalists to resolve their own contradictions symbolically, at least momentarily, by expulsion of the guilty' (Eason, 1988: 224) and to 'showcase the central virtues of journalism' by 'shor[ing] up the boundary between fact and fiction' (Carey, 2003: 5). In those ways, the contradictions between journalism's ideals and practices and between its 'informative, civic, and rational sides' and its 'pleasure-inducing, entertaining, or simply affective ones' (Zelizer, 2004: 190) are resolved or put back under wraps. Furthermore, expelling the guilty party "explains away" the faults, problems, or issues raised by the individual' without examining those problems and issues too closely (Lule, 2001: 79).

'Bad' journalists have regularly appeared in journalism movies just as they have in real-world journalism. The movies have paralleled other genre films in presenting characters who represent opposing cultural values. In a typical plot, a reporter interacts with an editor concerning a story that is embodied by another character or characters. A love interest also frequently appears. Conflicts over news and romance point to conflicts and contradictions at journalism's core.

The following overview, which is drawn from a broader study of journalism movies (Ehrlich, 2004), examines how prominent examples of the genre have resolved those conflicts. Again, the films have responded to changes in historical and social context, and they have portrayed certain aspects of journalism critically. However, they have also demonstrated how 'bad' and 
unprofessional journalists help underscore the professional allegiance to facts and truth.

\section{The Front Page and early journalism movies}

Ben Hecht and Charles MacArthur's 1928 stage farce The Front Page and the 1931 film version of the play were the prototypes of the journalism movie genre. According to Schmuhl (2003), The Front Page still influences 'how journalists think, talk, and act'. Some have credited it with drawing them into the craft (Ghiglione, 1990: 8-9; Hewitt, 2001: 14-15).

To a degree, such popularity is ironic given the authors' background and the play's tone. Hecht is listed as another of the Newseum's 'Newsmongers' (Newton, 1999: 14). He was a reporter in 'the sketch-hoax writer and the literary artisan' tradition of Chicago journalism (Sims, 1979: 44), in which sardonicism was a badge of honor. Hecht (1954: 142) later wrote that he and his newspaper colleagues took 'gleeful part in the destruction of the world' by heaping contempt on 'the mayor, the chief of police, women, literature, politics and morality'. MacArthur, meanwhile, worked at Hearst's Chicago Herald-Examiner under editor Walter Howey, who 'did not operate his paper by any code of ethics dreamed up at journalism school in an ivory tower full of idealistic professors' (Murray, 1965: 180).

Hecht and MacArthur drew liberally upon that background in writing their play. They turned Howey into the character of Walter Burns and described him in their stage directions as a 'product of thoughtless, pointless, nerve-drumming unmorality' (Hecht and MacArthur, 1928: 129). The other protagonist was Hildy Johnson, a reporter determined to escape newspapers and Walter Burns's clutches once and for all. 'Journalists!' Hildy sneeringly says early in the play. 'A lot of lousy, daffy buttinskis. . A cross between a bootlegger and a whore' (Hecht and MacArthur, 1928: 40). Hildy comes to the press room of the Chicago criminal courts building to bid his reporter pals adieu before departing for a New York advertising job with his fiancée Peggy, who wants him 'to be decent and live like a human being' (Hecht and MacArthur, 1928: 137). That proves difficult after convicted murderer Earl Williams escapes from jail on the eve of his scheduled execution and lands in the press room. Walter and Hildy hide him from rival reporters as well as from the mayor and sheriff, who want to hang Williams to win votes.

The Front Page presents a 'nightmare landscape' of 'universal corruption' (Harvey, 1987: 89). The government officials are extraordinarily opportunistic and venal, and the journalists are every bit the 'daffy buttinskis' that Hildy has branded them. When Williams escapes, Hildy and Walter hide him solely for 
the sake of an exclusive; when the rival reporters guess that a friend of Williams knows something about it, they hound and threaten her until she jumps out the upper-story press room window. The play's producer said the central theme was that 'once you get caught in the lousy newspaper business you can never get out again' (Harris, 1979: 118). New York Times attorney George Gordon Battle (1928: 2) wrote an editorial criticizing the play's 'profane and filthy dialogue' and its implication that journalists were 'all drunkards or roués'.

Such condemnations overlooked how The Front Page at its heart celebrated journalism. Hecht and MacArthur (1928: 191-2) noted that rather than producing a 'work which would reflect our intellectual disdain of and superiority to the Newspaper', they wrote 'a romantic and rather doting tale'. Despite Hildy and Walter's comic blunders and misdeeds, they triumph in the end by uncovering the truth. They expose the mayor and sheriff's plot to suppress a gubernatorial pardon of Earl Williams, and score the scoop of a lifetime.

The Front Page was the product of its times in how it reflected Hecht and MacArthur's nostalgia for their youthful reporting days as well as early 20thcentury reporters' fascination with big-city lowlifes and bohemian lifestyles. At the same time, it helped establish the enduring archetype of the 'harddrinking, fun-loving reporter, a member of a unique fraternity' (Ghiglione, 1990: 8-9), who 'considered himself, somewhat loonily, to have no boss, to be without superiors and a creature always on his own' (Hecht, 1954: 191). Such characters were diametrically opposed to the model of sober professionalism then taking hold in journalism and epitomized by the New York Times. Still, they provided a highly appealing model of their own by 'being cynical and clear-eyed and unappeasable in [their] bitterest knowledge-and being rewarded for it all' (Harvey, 1987: 89-90).

Sardonic, fast-talking journalists became familiar figures in the movies that followed The Front Page, but not all were comic heroes. Five Star Final (1931) was based on a Broadway play by Louis Weitzenkorn, a onetime tabloid newspaper editor. The movie focuses on a similar editor named Randall. His publisher Hinchecliffe and his sales managers are alarmed over a circulation decrease. At their urging, Randall dredges up a 20-year-old scandal concerning Nancy Voorhees, who had killed her boss after he impregnated her and then refused to marry her. The series about her past drives Voorhees and her husband to suicide, and their daughter bursts into the newspaper office seeking revenge with a gun. After she is disarmed, Randall phones in his resignation: 'Take your love nest killings to Hinchecliffe with my compliments! And tell him to shove it up his ...' He then hurls the phone through the plate glass window of the publisher's door. The film concludes with a tabloid front page being splattered with mud and swept into the gutter. 
The Front Page had shown journalists harassing people, but it had not dwelled on the pain they had caused. In contrast, Five Star Final explicitly condemned journalists whose unscrupulous behavior gravely harmed the innocent. As such, it and other films like it aroused the ire of real-life journalists to an extent that The Front Page had not (Nasaw, 2000: 445-6; Stockbridge, 1931). Louis Weitzenkorn, however, distinguished the respectable press from the tabloid papers his play indicted. He dedicated the play to his former editor at the New York World: 'The ethics of journalism learned from him made the author of Five Star Final a failure as a tabloid editor' (Weitzenkorn, 1931: v). Five Star Final was a morality tale, the excoriation and expiation of its protagonist underscoring norms of professional, ethical, truthful journalism.

\section{The screwball era}

'Newsmonger' characters were common in the screwball comedies of the 1930s and 1940s. Saltzman (2002: 1-2) describes the reporter protagonist of Frank Capra's It Happened One Night (1934) as a 'big-city, wisecracking shyster who talks fast, thinks fast, works fast, often lives by his wits, and won't take any crap from anyone'. At the same time, he represents 'a knight in shining armor, a part of the corruption of the city yet somehow above it, a combination of the illicit appeal of sin with the moral righteousness of being superior to those around him'. In the end, he is redeemed by romance as he weds the runaway heiress who originally was just a story to him. True to myth, screwball comedies smoothed away social rifts and contradictions, glossing over the Depression's misery with tales of working-class types who married into money (Schatz, 1981: 155-7). The movies' romantic happy endings also served to integrate maverick, outsider reporters into the cultural mainstream.

That is not to say the films always forced the journalists to surrender the iconoclastic qualities that made them attractive. In His Girl Friday (1940), a screwball remake of The Front Page, Hildy is now a woman reporter divorced from Walter. After breaking the Earl Williams story, she abandons her plans to leave the newspaper, marry an insurance man, and lead a 'halfway normal life'. Instead she reunites with Walter in the 'unifying, energizing, and eternally engaging profession' of journalism (Haskell, 1997: 115). Characters such as Hildy indicated that women could embody the same ethos that The Front Page's male journalists displayed, which DiBattista (2001: 271) describes as 'breezily indifferent to, when it is not downright contemptuous of, the decorum that regulates a "halfway normal life"'. The wisecracking female journalist 'was at home in reality and spoke its language' (DiBattista, 2001: 37), in contrast to the empty-headed lies and homilies to which others subscribed. 
However, female journalists of the screwball era could also inflict suffering, most notably in Frank Capra's post-It Happened One Night movies. In Mr. Deeds Goes to Town (1936), reporter Babe Bennett goes undercover to write stories mocking a small town man ('Mr. Deeds') who has come to New York to oversee his newly inherited fortune. Deeds falls for Bennett without knowing her real identity, and when he learns the truth, he is devastated. 'As swell a guy as ever hit this town, and you crucified him for a couple of stinking headlines', Deeds's press agent tells Bennett. At a hearing concerning whether Deeds should be stripped of his inheritance, Bennett confesses her sins and her love for Deeds. 'The newspapers pounced on him, made him a target for their feeble humor', she says. 'I got closer to him, so I could laugh louder ... He could never fit in with our distorted viewpoint, because he's honest and sincere and good.' Her speech rouses Deeds to defend himself, and at the end he has both his millions and Bennett. Once the woman reporter has repented, she is allowed the happy ending typical of Capra's films, giving up the 'distorted' world of tabloid journalism to live an honest and sincere life with Deeds.

Capra's Meet John Doe (1941) depicts a female journalist's fabrications being harnessed in support of an attempted takeover of the United States. Columnist Ann Mitchell concocts a story about 'John Doe', who purportedly will commit suicide to protest social conditions. Her paper takes up the scheme to boost circulation and hires a man to pose as Doe. When a John Doe movement promoting neighborliness and self-reliance sweeps the country, an evil media mogul exploits it for his own fascistic ends. The man playing Doe plans to commit suicide for real to protest the Doe movement's desecration, but Mitchell (who has fallen in love with him) persuades him to restore the movement to its original ideals. Here again, the journalist sees the error of her ways and forsakes a big city press that has been corrupted for something more real and true.

\section{The noir era}

Following the war years, the 'bad' journalist reappeared in such films noir as Ace in the Hole (1951), also known as The Big Carnival. The movie depicts unemployed New York reporter Chuck Tatum landing at an Albuquerque newspaper. His editor has hung embroidered signs reading 'Tell the Truth' on the newsroom walls. Tatum pays no heed and ruthlessly exploits the story of a man trapped in a cave. He convinces the local sheriff to draw out the rescue effort while at the same time he beds the trapped man's slatternly wife. The man in the cave contracts pneumonia and dies, and the man's wife stabs Tatum. Bleeding but still ambulatory, the guilt-stricken reporter returns to the Albuquerque newsroom. 'How'd you like to make yourself a thousand dollars 
a day?' he asks the editor. 'I'm a thousand-dollar-a-day newspaperman. You can have me for nothing.' With that, he topples over dead.

Much like Five Star Final before it, Ace in the Hole was excoriated by a number of journalists and reviewers, one of whom called it 'a brazen, uncalledfor slap in the face of two respected and frequently effective American institutions-democratic government and the free press' (Sikov, 1998: 326). In fact, the movie hardly could be clearer regarding what the press should do. Tatum is a self-schooled urban newshound obsessed with tabloid tales and stunts. In contrast, the editor is a voice of conscience who condemns Tatum for his 'phony, below-the-belt journalism'. The film's denouement, in which Tatum loses both his scoop and his life, brands his style of reporting as beyond the pale and affirms the editor's overriding belief in truth telling.

The noir classic Sweet Smell of Success (1957) has been called 'the hip American movie' (Buford, 2000: 177), but it too moralizes in its conclusion. Columnist J. J. Hunsecker appears to have unlimited power to make or break lives and careers. He has a virtually incestuous attachment to his sister and orders a toadying press agent to arrange the brutal beating of her fiancé. In the end, everything comes crashing down upon the columnist. The press agent (before he himself is beaten senseless) calls Hunsecker a 'big phony' and vows to reveal all. Hunsecker's sister goes so far as to express her pity for him before she abandons him for good.

Sweet Smell of Success and Ace in the Hole represented the flip side of contemporaneous movies such as Gentleman's Agreement and Deadline, USA that featured upstanding, professional journalists. Both sets of movies were inherently conservative, reflecting the perceived need during the Cold War era for 'a firm consensus on U.S. values' and on the strength and superiority of American institutions (Barnhurst and Nerone, 2001: 208). That included the press, as journalistic truth and virtue were celebrated and lies and other sins were punished.

\section{Conspiracy films}

Many 1970s movies have been labeled 'conspiracy' films. They show individuals confronting shadowy, evil forces rooted in government and business bureaucracies, and massive plots covering up dark and terrible truths (Pratt, 2001; Ryan and Kellner, 1988: 95-105). All the President's Men is one such film, as Woodward and Bernstein gradually expose the Watergate conspiracy in the face of daunting obstacles and warnings that their lives are in danger.

Other movies of the time portrayed the news media in a decidedly less triumphant light. Prior to directing All the President's Men, Alan J. Pakula also directed The Parallax View (1974), in which a scruffy, countercultural reporter 
goes undercover to investigate a string of political assassinations. He increasingly mistrusts official explanations for the killings, while his editor scolds him for his unprofessional behavior and dismisses his claims of a conspiracy. The 'outsider' journalist sees truths that others cannot or will not see, as the editor dies at the hands at the conspiracy. Before the reporter is able to report the truth to the public, he too is killed, and a government commission suppresses the sinister details. Pakula said the film expressed 'my view of what's happening in the world. . the individual [being] destroyed in a secret maze by forces of which he has no knowledge' (Pratt, 2001: 130). Such views are a common theme of conspiracy stories (Melley, 2000).

A similar perspective appears in Paddy Chayefsky's Network (1976). Newscaster Howard Beale is another incarnation of the journalist as iconoclast and critic, urging his viewers to turn off their televisions before the medium and its corporate masters destroy their minds and souls: 'Television is not the truth! Television is a goddamned amusement park!' However, he is turned into a ratings gimmick by the new news division head, Diana Christensen. As in The Parallax View, there is no happy ending; Christensen and her cronies have Beale murdered on the air in another effort to boost ratings.

For all of Network's savage (and prophetic) satire, it also demonstrates a liberal-minded belief in individual autonomy and a populist mistrust of social controls that threaten that autonomy. The movie graphically warns what can happen when reason and truth - central tenets of professional journalism - are subsumed by entertainment and business concerns. Christensen is made a straw woman for all those ills. 'You're madness, Diana', says the veteran news executive whose love for Christensen has brought him only misery. 'War, murder, death: all the same to you as bottles of beer. And the daily business of life is a corrupt comedy. . . Everything you touch dies with you.'

\section{Contemporary films}

Post-Watergate movies have continued to present resolutely unprofessional journalists, some based upon real-life models. Hunter S. Thompson himself was impersonated by Bill Murray in Where the Buffalo Roam (1980) and Johnny Depp in Fear and Loathing in Las Vegas (1998). The reporting experiences of another gonzo type, Richard Boyle, inspired Salvador (1986). In the movie, Boyle's wife and child leave him after his drunken misdeeds derail his journalism career. He heads to El Salvador looking for sex and drugs only to be plunged into the midst of a brutal civil war. The reporter becomes radicalized and harangues American military advisors: 'I believe in America. I believe that we stand for something. For a constitution. For human rights, not just for a few people, but for everybody on this planet!' Again, the outsider journalist 
is one of the few willing to question official lies and take risks to report the truth.

Wholly fictional journalists also drew upon the gonzo image as well as upon movies of earlier eras. In The Paper (1994), a tabloid columnist fires a gun to get attention in the newsroom and sleeps on a couch there, apparently having no other home. Alongside his antics, he bluntly makes the managing editor see her mistake in squelching a factual story that can free two youths accused of murder. In True Crime (1999), Clint Eastwood plays an alcoholic, womanizing reporter who lost his previous newspaper job for cavorting with the owner's daughter and who now is sleeping with his editor's wife. When he gets a hunch that a prisoner scheduled to be executed the next day is innocent, he interviews the condemned man. 'I don't care about justice in this world or the next', he tells the prisoner. 'But you know what this is? . . That's my nose .. . When my nose is working well, I know there's truth out there somewhere.' The reporter saves the man's life at the last possible moment by delivering the facts about the real killer to the governor's mansion. He wins a book deal and a Pulitzer Prize nomination, but his wife leaves him. At the movie's close, the reporter has just bought a Christmas gift for his daughter from whom he is now separated. 'Santa Claus rides alone', he growls before dropping his cigarette and loping off into the night.

Unprofessional conduct also has been punished in contemporary movies. Such is the case in Absence of Malice (1981), which has been cited (Schudson, 1992: 120) as an example of the anti-press sentiments of the post-Watergate era. In actuality, it is another morality tale focusing on a wayward reporter discovering the errors of her ways. She allows herself to be manipulated into writing a story that wrongly implicates a liquor wholesaler in the disappearance of a union leader. She then writes another story that leads to the suicide of the wholesaler's close friend, prompting the grief-stricken man to assault her. The reporter's misconduct is abetted by her editor and the newspaper's oily attorney, who tells her that under First Amendment law, the truth of what she reports is 'irrelevant'. Finally, the wholesaler gets even with all who have injured him and his friends; the reporter and her paper are publicly disgraced. 'I know you think what I do for a living is nothing', she tells the wholesaler at the end of the film. 'But it isn't really nothing: I just did it badly.' The implication is that having learned from her mistakes and been made an example, she may one day practice her profession correctly.

Shattered Glass (2003) shows young Stephen Glass rising to fame at The New Republic by fabricating more than two dozen sardonic pieces on the political and cultural scene. He deflects scrutiny by charming his colleagues and manipulating the magazine's fact-checking system. Eventually he becomes the target of another news organization's investigation, prompting the New Republic's unpopular but principled editor Chuck Lane to challenge the 
veracity of his reporting. 'If you want me to say that I made it [all] up, I will', Glass tells Lane. 'I just want you to tell me the truth, Steve', Lane replies. When Glass continues to lie, Lane fires him and defends the decision to Glass's closest friend on the magazine: 'We're all going to have to answer for what we let happen here ... He handed us fiction after fiction, and we printed them all as fact, just because we found him entertaining. It's indefensible.' At the end, Lane has won the full respect of his staff, and Glass is left jobless and alone in his make-believe world (Ehrlich, 2005).

\section{Discussion}

Bad journalists in the movies have played much the same role that such characters have in real-world journalism: They have supported the idea that the press has a 'capacity to narrativize the events of the real world' through its 'attentiveness to how things "really" happe[n]' (Zelizer, 2004: 190). In other words, they suggest that journalists have a unique ability to see the world as it really is and a unique responsibility to tell factual and truthful stories about it. Such portrayals in turn reinforce journalism's cultural identity and authority.

Saltzman (2002: 146) notes that in movies, a journalist 'can lie, cheat, distort, bribe, betray, or violate any ethical code as long as the journalist exposes corruption, solves a murder, catches a thief, or saves an innocent'. Bad or unprofessional behavior is excusable if ultimately the journalist reports facts and truth in the public interest. On the other hand, if a journalist's actions serve only 'his or her personal, political, or financial gain, if the end result is not in the public interest ... evil has won out. The only possible salvation is resigning and leaving the profession-or death' (Saltzman, 2002: 146). Such characters do their part in 'affirming and defending social consensus' by suffering the 'dark consequences for those who deviate' from society's norms (Lule, 2001: 62-3).

In dramatically depicting how important it is for journalism to serve the public interest, movies reproduce what Bennett (2005: 241) calls the 'myth of a free press'. Under that myth, a 'commercial free press system is thought to be ordained by the Founding Fathers as the engine of participatory selfgovernment' (McChesney and Scott, 2004: 1). That thought is closely bound up with the model of professional, socially responsible journalism that began to develop in the early 20th century and that took firm hold by the postSecond World War era. It assumes that journalism can and should objectively separate truth from falsehood in presenting 'truthful, comprehensive, and intelligent' news in a meaningful context (Peterson, 1963: 93-4). It also assumes that the commercial press should regulate itself and that individual 
journalists and news organizations should independently decide what truth the public needs to know (Black et al., 1999; Nerone, 1995).

However, according to Bennett (2005: 241) and other critical media scholars, such myths 'stand in the way of seeing the realities of power'. They obscure the commercial, professional press's coziness with dominant political and economic interests, smoothing over inherent tensions between public interest and private profit as well as between objective truth and subjective interpretation.

'Bad' journalist characters flout professional rules and niceties, but do their part in perpetuating the same myths. They keep alive the nostalgic image of the journalist as a rugged, anti-authoritarian individualist who sticks up for the common man and woman rather than being a stenographer to power (Barsamian, 1992). When they put their selfish interests ahead of the public interest and are subsequently punished, they imply that journalistic failures are due to individual shortcomings and that the press 'system itself is beyond reproach' (McChesney and Scott, 2004: 1). By maintaining the legitimacy of that system, movies help sustain the status quo. They confer 'professional credibility' upon journalism by giving it 'a ready-made role in the ideal picture of American democracy' (Bennett, 2005: 241-2), that of independent truth teller and public servant.

As purveyors of myth, however, movies do not always necessarily 'serve and preserve social order'; they also potentially 'have the capacity to change the social order' (Lule, 2001: 191-2), or at least highlight the contradictions within it. That again is an important role of genre films, to criticize cultural norms and values even as they reinforce them (Schatz, 1981). Journalism movies point toward a key concern of cultural studies of the press: 'the tensions between how journalism likes to see itself and how it looks in the eyes of others' (Zelizer, 2004: 178). That 'newsmonger' characters have persisted and played similar roles in both movies and real-life journalism suggests that 'journalism is something part of, rather than separate from, popular culture' (Dahlgren, 1992: 18), and that the press's attempts to enforce the boundaries between serious news and pleasurable entertainment never have been wholly successful.

What is more, if movies' depictions of the press have tended to uphold the image of professional journalism as an instrument for the 'transfer of socially and politically useful information' (Dahlgren, 1992: 7), they also have contradicted that image by depicting journalists engaged in egregiously unprofessional behavior (a major reason, of course, why journalists themselves have objected to such portrayals). In addition, they have pointed toward failings in the commercial 'free press' system while responding to the concerns of their respective eras: the tabloid press's gravitation toward sensationalism and exploitation in Five Star Final, Mr. Deeds Goes to Town, and (in a particularly 
sinister and advanced form) Sweet Smell of Success; the political co-optation and suppression of the mainstream media in The Parallax View, Network and Salvador; the hiding of the press behind First Amendment privilege in Absence of Malice; the rewards conferred upon contemporary journalists who specialize in irony rather than substance in Shattered Glass; and so on.

Other movies similarly have highlighted contradictions in professional ideology. Citizen Kane (1941), for example, indicates that objective 'truth' is unachievable while also dramatizing 'the irresolvable conflict between American myths of success (celebrating energy and ambition) and of the simple life (warning that power and wealth corrupt)' (Ray, 1985: 57). In Under Fire (1983), a journalist furthers the cause of freedom by staging a news photo; in Broadcast News (1987), a television newscaster advances his career by faking tears on camera.

Even when movies reaffirm myths of a free press that at worst can encourage citizens to 'escape into an illusory world where democracy is operating just fine', the myths still can be 'inspirational, hopeful, ennobling' (Bennett, 2005: 241, 243). They indicate that truth is sacred, that journalists can help bring that truth to light, and that citizens can act upon that truth in governing themselves. Such assertions can seem naïve at a time when corporate media appear increasingly oblivious to, if not downright contemptuous toward, journalistic ideals of fairness and verification (Nerone and Barnhurst, 2003).

Nevertheless, as one film critic wrote in reviewing Shattered Glass, 'If truth isn't something worth making an issue about, let alone a movie, then should we not just abandon all pretence of civilization, grab our clubs and buffalo skins, and retreat to the caves of our prehistoric ancestors?' (Howell, 2003: D03). Journalism and cultural studies both have a stake in a 'shared commitment to the real world' and to 'the rights and responsibilities of an informed citizenry' (Zelizer, 2004: 184). We abandon myths of a free press and a free people at our peril. Movies - including those featuring bad journalists - depict a world in which the two cannot be separated.

\section{References}

Altman, Rick (1987) The American Film Musical. Bloomington: Indiana University Press.

Barnhurst, Kevin G. and John Nerone (2001) The Form of News. New York: Guilford. Barris, Alex (1976) Stop the Presses! New York: Barnes.

Barsamian, David (1992) Stenographers to Power. Monroe, ME: Common Courage. Battle, George Gordon (1928) 'Stage Profanity Again Under Fire', New York Times, 9 September, sec. 10: 2 . 
Bennett, W. Lance (2005) News: The Politics of Illusion, 6th edn. New York: Pearson Longman.

Bennett, W. Lance, Lynne A. Gressett and William Haltom (1985) 'Repairing the News: A Case Study of the News Paradigm', Journal of Communication 35(2): 50-68.

Berkowitz, Dan (2000) 'Doing Double Duty: Paradigm Repair and the Princess Diana What-a-Story', Journalism: Theory, Practice and Criticism 1(2): 125-43.

Black, Jay, Bob Steele and Ralph Barney (1999) Doing Ethics in Journalism, 3rd edn. Boston, MA: Allyn and Bacon.

Brennen, Bonnie (2003) 'Sweat Not Melodrama: Reading the Structure of Feeling in All the President's Men', Journalism: Theory, Practice and Criticism 4(1): 113-31.

Brennen, Bonnie (2004) 'From Headline Shooter to Picture Snatcher: The Construction of Photojournalists in American Film, 1928-1939', Journalism: Theory, Practice and Criticism 5(4): 423-39.

Buford, Kate (2000) Burt Lancaster. New York: Knopf.

Carey, James W. (1988) 'Taking Culture Seriously', in James W. Carey (ed.) Media, Myths, and Narratives. Newbury Park, CA: Sage.

Carey, James W. (2003) 'Mirror of the Times', The Nation 276(16 June): 5-6.

Cecil, Matthew (2002) 'Bad Apples: Paradigm Overhaul and the CNN/Time "Tailwind" Story', Journal of Communication Inquiry 26(1): 46-58.

Chaloupka, William (1999) Everybody Knows: Cynicism in America. Minneapolis: University of Minnesota Press.

Cohen, Rich (2005) 'Gonzo Nights', New York Times Book Review 17 April, sec. 7: 12.

Dahlgren, Peter (1992) 'Introduction', in Peter Dahlgren and Colin Sparks (eds) Journalism and Popular Culture. London: Sage.

DiBattista, Maria (2001) Fast-Talking Dames. New Haven, CT: Yale University Press.

Drewry, John E. (1931) 'Presidential Address: The Journalist's Inferiority Complex', Journalism Quarterly 8: 12-23.

Eason, David L. (1988) 'On Journalistic Authority: The Janet Cooke Scandal', in James W. Carey (ed.) Media, Myths, and Narratives. Newbury Park, CA: Sage.

Ehrlich, Matthew C. (2004) Journalism in the Movies. Urbana: University of Illinois Press.

Ehrlich, Matthew C. (2005) 'Shattered Glass, Movies, and the Free Press Myth', Journal of Communication Inquiry 29: 103-18.

Evensen, Bruce J. (1989) 'Journalism's Struggle over Ethics and Professionalism during America's Jazz Age', Journalism History 16(3-4): 54-63.

Fallows, James (1997) Breaking the News. New York: Vintage.

Ghiglione, Loren (1990) The American Journalist. Washington, DC: Library of Congress.

Ghiglione, Loren and Joe Saltzman (2002) 'Fact or Fiction: Hollywood Looks at the News', Image of the Journalist in Popular Culture Journal, URL (consulted Jan. 2005): http://www.ijpc.org/journal.html.

Good, Howard (1989) Outcasts. Metuchen, NJ: Scarecrow.

Good, Howard (1998) Girl Reporter. Lanham, MD: Scarecrow.

Good, Howard (2000) The Drunken Journalist. Lanham, MD: Scarecrow.

Hanson, Christopher (1996) 'Where Have All the Heroes Gone?', Columbia Journalism Review 34 (March/April): 45-8.

Harris, Jed (1979) A Dance on the High Wire. New York: Crown.

Harvey, James (1987) Romantic Comedy. New York: Alfred A. Knopf. 
Haskell, Molly (1997) Holding My Own in No Man's Land. New York: Oxford University Press.

Hecht, Ben (1954) A Child of the Century. New York: Simon and Schuster.

Hecht, Ben and Charles MacArthur (1928) The Front Page. New York: Covici-Friede.

Hewitt, Don (2001) Tell Me a Story. New York: Public Affairs.

Howell, Peter (2003) 'Big Game of Untruths and Consequences', Toronto Star (28 November): D03.

Kaufman, Alan, Neil Ortenberg and Barney Rosset (eds) (2005) The Outlaw Bible of American Literature. New York: Thunder's Mouth.

Keil, Richard (2005) 'An American Original', American Journalism Review 27 (April/ May): 60-2.

Kovach, Bill and Tom Rosenstiel (2001) The Elements of Journalism. New York: Crown.

Langman, Larry (1998) The Media in the Movies. Jefferson, NC: McFarland.

Leuchtenburg, William E. (1995) 'All the President's Men', in Mark C. Carnes (ed.) Past Imperfect. New York: Henry Holt.

Lule, Jack (2001) Daily News, Eternal Stories. New York: Guilford.

McChesney, Robert W. and Ben Scott (2004) 'Introduction', in Robert W. McChesney and Ben Scott (eds) Our Unfree Press. New York: New Press.

Melley, Timothy (2000) Empire of Conspiracy. Ithaca, NY: Cornell University Press.

Mukerji, Chandra and Michael Schudson (1991) 'Introduction', in Chandra Mukerji and Michael Schudson (eds) Rethinking Popular Culture. Berkeley: University of California Press.

Murray, George (1965) The Madhouse on Madison Street. Chicago, IL: Follett.

Nasaw, David (2000) The Chief: The Life of William Randolph Hearst. Boston, MA: Houghton Mifflin.

Nerone, John C. (ed.) (1995) Last Rights. Urbana: University of Illinois Press.

Nerone, John and Kevin G. Barnhurst (2003) 'US Newspaper Types, the Newsroom, and the Division of Labor', Journalism Studies 4(4): 435-49.

Ness, Richard R. (1997) From Headline Hunter to Superman. Lanham, MD: Scarecrow.

Newton, Eric (ed.) (1999) Crusaders, Scoundrels, Journalists. New York: Times Books.

Peterson, Theodore (1963) 'The Social Responsibility Theory of the Press', in Fred S. Siebert, Theodore Peterson and Wilbur Schramm Four Theories of the Press. Urbana: University of Illinois Press.

Pratt, Ray (2001) Projecting Paranoia. Lawrence: University Press of Kansas.

Ray, Robert B. (1985) A Certain Tendency of the American Cinema. Princeton, NJ: Princeton University Press.

Rich, Frank (2005) 'Gonzo Gone, Rather Going, Watergate Still Here', New York Times 6 March, sec. 2: 1.

Rowe, Chip (1992) 'Hacks on Film', Washington Journalism Review, 14(November): 27-9.

Ryan, Michael and Douglas Kellner (1988) Camera Politica. Bloomington: Indiana University Press.

Saltzman, Joe (2002) Frank Capra and the Image of the Journalist in American Film. Los Angeles, CA: Image of the Journalist in Popular Culture.

Schatz, Thomas (1981) Hollywood Genres. New York: McGraw-Hill.

Schmuhl, Robert (2003) 'The Front Page Turns 75', Poynter Online, URL (consulted Jan. 2005): http://www.poynter.org/content/content_view.asp?id $=43784$.

Schudson, Michael (1978) Discovering the News. New York: Basic. 
Schudson, Michael (1991) 'The Sociology of News Production Revisited', in James Curran and Michael Gurevitch (eds) Mass Media and Society. London: Arnold.

Schudson, Michael (1992) Watergate in American Memory. New York: Basic.

Schudson, Michael and Susan E. Tifft (2005) 'American Journalism in Historical Perspective', in Geneva Overholser and Kathleen Hall Jamieson (eds) The Press. New York: Oxford University Press.

Sikov, Ed. (1998) On Sunset Boulevard. New York: Hyperion.

Sims, Norman Howard (1979) 'The Chicago Style of Journalism', PhD dissertation, University of Illinois.

Slotkin, Richard (1998) Gunfighter Nation. Norman: University of Oklahoma Press.

Stockbridge, Frank Parker (1931) 'Public Gets False Picture of Journalism', American Press 50(November): 1-2.

Vaughn, Stephen and Bruce Evensen (1991) 'Democracy's Guardians: Hollywood's Portrait of Reporters, 1930-1945', Journalism Quarterly 68: 829-38.

Weitzenkorn, Louis (1931) Five Star Final. New York: Samuel French.

Wright, Will (1975) Sixguns and Society. Berkeley: University of California Press.

Zelizer, Barbie (2004) Taking Journalism Seriously. Thousand Oaks, CA: Sage.

\section{Biographical notes}

Matthew C. Ehrlich is Professor of journalism at the University of Illinois at UrbanaChampaign. He is the author of Journalism in the Movies (University of Illinois Press, 2004). His research on journalism, myth, and popular culture has appeared in Journalism and Communication Monographs, Critical Studies in Media Communication, and Journalism and Mass Communication Quarterly.

Address: Department of Journalism, University of Illinois at Urbana-Champaign, 119 Gregory Hall, 810 S. Wright St., Urbana IL 61801, USA. [email: mehrlich@ uiuc.edu] 